\title{
Vanguard of the Imam: Religion, Politics, and Iran's Revolutionary Guards. By Afshon Ostovar. New York, N.Y.: Oxford University Press, 2016.
}

Follow this and additional works at: https://digitalcommons.usf.edu/jss pp. 133-136

\section{Recommended Citation}

"Vanguard of the Imam: Religion, Politics, and Iran's Revolutionary Guards. By Afshon Ostovar. New York, N.Y.: Oxford University Press, 2016.." Journal of Strategic Security 9, no. 2 (2016) : 133-136.

DOI: http://dx.doi.org/10.5038/1944-0472.9.2.1529

Available at: https://digitalcommons.usf.edu/jss/vol9/iss2/10

This Book Review is brought to you for free and open access by the Open Access Journals at Digital Commons @ University of South Florida. It has been accepted for inclusion in Journal of Strategic Security by an authorized editor of Digital Commons @ University of South Florida. For more information, please contact digitalcommons@usf.edu. 


\section{Vanguard of the Imam: Religion, Politics, and Iran's Revolutionary Guards. By Afshon Ostovar. New York, N.Y.: Oxford University Press, 2016.}




\section{Vanguard of the Imam: Religion, Politics, and Iran's Revolutionary Guards. By Afshon Ostovar. New York, N.Y.: Oxford University Press, 2016. ISBN 978-0-19-938789-2. Maps. Photographs. Graphics. Glossary. Index. Notes. Sources cited. Pp. xiv, 306. \$34.95.}

Afshon Ostovar's Vanguard of the Imam fills a much needed void on the topic of Iran's Islamic Revolutionary Guard Corps (IRGC). It is perhaps the most comprehensive, holistic view of the IRGC since Kenneth Katzman's groundbreaking work The Warriors of Islam (1993). Ostovar is an Assistant Professor of National Security Affairs at the Naval Postgraduate School and writes for any audience seeking to better understand the social, political, jurisprudential, psychological, sociological, and anthropological underpinnings of modern Iran. The book is well written and for the most part flows smoothly, only occasionally diving deeply into the details of how various factions in Iran interact with each other.

Ostovar posits that the IRGC are the defenders of Iran's Supreme Leader, which imbues them with a sacred air, enables them to demonize their enemies, and allows them to cast their struggle in almost Zoroastrian terms of good and evil at the cosmic level. Their activities are crafty, carefully calculated, and replete with political machinations, intent on keeping the revolutionary flame alive.

The IRGC is a security, intelligence, counterintelligence, social political, religious, industrial, and economic entity. It is also a military organization with both regular and paranormal organs that operate on land, sea, and air with asymmetric tactics and strategy. It operates within Iran, as well as abroad. Its members serve as ideological commissars and morals police. Its pro-cleric coercive activism buttresses the most extreme factions of Iran as it reaches into every level of Iranian society. Its economic clout is powerful, with lucrative no-bid government contracts for dams, railroads, industry, natural gas, telecommunications, shipping, media, and infrastructure.

Ostovar traces the IRGC's development from its origins during the Iranian Revolution of 1979 and its symbiotic relationship with Iran's Supreme Leader. Iran as an Islamic Republic is founded on the principle of veleyate faqih (rule of the jurisprudent), which gives the Supreme Leader political 
and religious authority. Upheld unconditionally by the IRGC, the Supreme Leader showers them with political and economic favors.

The author traces the IRGC from the heady days of the 1979 revolution and outlines the IRGC's role in state building. He provides an historical and religious framework of Shi'a Islam to give context to the IRGC's ideological underpinnings. In that setting, he shows how Ayatollah Khomeini used them to impose order, eliminate rivals, control the infrastructure, and consolidate power. Khomeini inflamed and used their religious zeal to foster support for the new regime.

During the Iran-Iraq war, the IRGC drove Tehran's war effort as a "divine cause" inspired by a "divine power." Due to religious zeal and tremendous sacrifice, they became a cornerstone of Iran's warfighting capability. Waging guerrilla war against a better equipped and trained Iraqi army, they learned how to use mobility, terrain, psychological warfare, martyrdom, and self-sacrifice to defend their homeland. At the same time, the IRGC fought Iran's internal foes and carried out ruthless political purges. Once the internal uprisings were contained, the IRGC redoubled its efforts against Iraq, utilizing human wave attacks reminiscent of Japan's kamikaze approach in WWII. Harnessing religious zeal, the IRGC used countless Iranians as cannon fodder in a religious war that decimated a generation of Farsi youth.

Following the Iran-Iraq war, the IRGC became a paramount military force as it attained status as a government ministry with political capital to spare. Self-identifying as guardians of the Islamic Revolution, the IRGC took a "the best defense is a good offense" approach, and went abroad to export that revolution. The IRGC went to assist the fledgling Hezbollah after the Israeli invasion of Lebanon in 1982. While the author briefly mentions the IRGC role in setting up Hezbollah, this section of the book is sorely lacking in detail, making for an unsatisfying treatment of the topic. A better discussion of the topic can be found in Matthew Levitt's book Hezbollah.

As the IRGC matured, it refined the religious requirements for its members through stringent ideological and political quality controls to ensure members would fight for the cause of God. After the 1989 death of Ayatollah Khomeini, the IRGC established the Quds (Jerusalem) Force (IRGC-QF), a terrorist branch conducting direct action and special 
operations. As a military industrial power broker with lucrative state contracts, unregulated import/export activities, it became an everexpanding power base. Surprisingly, there is no mention of the Khobar Towers terrorist attack, in which the IRGC played a major role. This glaring omission, along with the failure to discuss the IRGC's sponsorship of Hezbollah, are the book's main flaws. The author missed an incredible opportunity to explore and develop these key themes of history.

After the September 11, 2001 attacks, Iran worked cooperated behind the scenes with the United States to fight al-Qa'ida and the Taliban. The author gave short shrift to IRGC activities in Afghanistan, which would have been helpful to understand their role in Central Asia. Tehran was displeased by President Bush's inclusion of Iran as part of an axis of evil. After the fall of Saddam Hussein, the IRGC was glad to fill the resultant power vacuum in Iraq, supplying weapons used against U.S. military forces and carrying our anti-U.S. operations. While there are a few pages on this topic, Steven O'Hern's Iran's Revolutionary Guard discusses IRGC anti-U.S. operations in Iraq with much more granularity. It's almost as if the author wants to magnify U.S. flaws while minimizing Iranian misdeeds.

Ostovar discusses IRGC interference in Iran's 2005 and 2009 elections as the organization mistreated, beat, tortured, and raped political prisoners. He also addresses the IRGC plot to assassinate the Saudi Ambassador the U.S. by using Mexican drug lords. He briefly discusses the IRGC role in the terrorist attack in Burgas, Bulgaria.

The author outlines IRGC activities: Exploiting the power vacuum in Iraq, fighting the Islamic State, supporting the Syrian dictator Assad, and using the defense of Islam as an umbrella to carry out myriad activities. As a cornerstone of the Islamic Republic, it has an impact in the political social, economic, and cultural arenas. Purging its rivals, it bolsters the regime and stands as an anti-U.S. force to combat Washington's influence in the region.

Ostovar's book gives great insight into the IRGC's structure and ideological underpinnings. The book is relevant for the dedicated Iran hand, one seeking understanding of IRGC ideology, and the student of Iranian regime stabilization. It falls short on the IRGC's role in Lebanon, in orchestrating the Khobar Tower attack, and could have delved into more 
detail regarding activities in Iraq and Afghanistan. Overall uneven, it is yet a tome with valuable perspectives.

Mark J. Roberts is a subject matter expert 